\title{
ОЦЕНКА ПОЛНОТЫ СОВЕРШЕНИЯ ИСПОЛНИТЕЛЬНЫХ ДЕЙСТВИЙ ПРИ ОСУЩЕСТВЛЕНИИ ПРОКУРОРСКОГО НАДЗОРА ЗА ЗАКОННОСТЬЮ ДЕЙСТВИЙ СУДЕБНЫХ ПРИСТАВОВ
}

\section{EVALUATION OF THE COMPLETENESS OF THE PERFORMANCE OF EXECUTIVE ACTIONS IN THE IMPLEMENTATION OF PROSECUTOR'S SUPERVISION OVER THE LEGALITY OF THE ACTIONS OF BAILIFFS}

M. Gadiyatova

Summary: The author in this article consider the conditions for improving the efficiency of contest the actions of enforcement proceeding of Federal Bailiff Service. The article notes both the problems of performance of prosecutorial supervision and the actions of public officials of Federal Bailiff Service. The author makes a strong case for increase the bailiff's powers to apply for annulment of the illegal transaction concerning the debtor's property.

Keywords: bailiff, prosecutor, law, enforcement proceeding, to invalidate the sale.

\author{
Гадиятова Мария Витальевна \\ К.ю.н., дочент, ФГБОУ ВО «Уральский государственный \\ юридический университет» (УрГЮУ) \\ gadiyatovam@inbox.ru
}

Аннотация: В настоящей статье автор рассматривает условия повышения эффективности работы судебных приставов в ходе исполнительного производства. В работе отмечаются проблемы как осуществления прокурорского надзора за исполнением законов судебными приставами, так и исполнения судебных актов, путей повышения эффективности в работе судебных приставов. Автором аргументируется позиция о необходимости расширения полномочий судебных приставов-исполнителей и предоставления им права на предъявление исков о признании недействительными сделок, совершенных должником в целях отчуждения своего имущества.

Ключевые слова: судебный пристав, прокурор, законность, исполнительное производство, признание сделки недействительной.
$\mathrm{B}$ соответствии с положениями Конституции Российской Федерации, а также практикой применения Конвенции о защите прав человека и основных его свобод защита нарушенных прав не может быть признана действенной, если судебный акт или акт иного уполномоченного органа своевременно не исполняется. Проблема исполнения судебных актов наряду с ежегодным увеличением количества дел, рассматриваемых судами общей юрисдикции и арбитражными судами, придает прокурорскому надзору за исполнением законов судебными приставами особую значимость. Осуществляя надзор за исполнением законов судебными приставами, целью деятельности прокуратуры является восстановление прав, свобод и законных интересов граждан в ходе исполнения судебных решений. В связи с этим одним из наиболее важных аспектов надзора за судебными приставами это соблюдение принципов своевременности осуществления исполнительных действий и полноты взысканий по исполнительным документам.

Надзорные полномочия прокурора за законностью действий судебных приставов-исполнителей не только не регламентированы специальной нормой, но и нормы законодательства о прокуратуре не предусматривают дополнительных полномочий по отношению к полномочиям прокурора в ходе осуществления «общенадзорной» деятельности. Тем самым у прокуратуры
Российской Федерации снижается эффективность прокурорского надзора, а Федеральная служба судебных приставов не достигает своего главного показателя окончания исполнительного производства фактическим исполнением.

В настоящее время можно наблюдать реформирование системы органов принудительного исполнения, что связано изменением законодательства о службе, а также правового статуса судебных приставов, что также играет огромную роль в достижении показателей эффективности системы принудительного исполнения. Однако указанного факта недостаточно. Изменения должны коснуться и полномочий судебных приставов-исполнителей, предоставляемых им в ходе исполнительного производства, что должно отразиться на осуществлении органами прокуратуры надзорной деятельности в рассматриваемом направлении.

Оценивая положения законодательства об исполнительном производстве, можно заключить о широком объеме полномочий, предоставленных судебным приставам-исполнителям. Судебные приставы вправе накладывать арест на имущество должника с момента возбуждения исполнительного производства или на стадии добровольного исполнения исполнительного документа, что позволяет оценить указанное право, как самосто- 
ятельную от суда обеспечительную меру и является гарантом защиты прав и законных интересов взыскателя. [5c. 3.] Правовой инструментарий в деятельности судебных приставов состоит также в привлечении должников по исполнительным производствам к административной ответственности, взаимодействии с органами полиции по осуществлению принудительных исполнительных действий, праву на применение физической силы, специальных средств. Существенно повышают эффективность в ходе исполнительного производства введение ограничительных мер в отношении должника, быстрота их реализации в обмене информацией с уполномоченными органами. В соответствии со статьей 64 Федерального закона «Об исполнительном производстве» (далее - Закон о исполнительном производстве) судебному приставу-исполнителю предоставлен ряд правомочий, реализуемых как на стадии добровольного, так и принудительного исполнения исполнительных документов, имеющих целью создание условий для применения мер принудительного исполнения, а также на понуждение должника к полному, правильному и своевременному исполнению требований, содержащихся в исполнительном документе. [1]. Перечень указанных полномочий не является исчерпывающим и допускает возможность совершения органами принудительного исполнения иных действий, необходимых для своевременного, полного и правильного исполнения. Указанное полномочие является, на наш взгляд, ключевым, так как предоставляет органам принудительного исполнения возможность в рамках правового поля совершать какие-либо еще полномочия, необходимые для создания условий для исполнения судебных актов или иных исполнительных документов. На практике иные полномочия могут быть выражены в запрете на проведение регистрационных действий в налоговых органах, в отношении имущества должника, налагаемого в целях обеспечения исполнения требований исполнительного документа, в розыске должников через социальные сети или иные интернет ресурсы и другие. [2].

Проверка законности совершения судебным приставом-исполнителем иных действий в рамках рассматриваемой нормы Закона об исполнительном производстве также является одним из элементов предмета прокурорской проверки.

Однако указанные полномочия органов принудительного исполнения зачастую оказываются неэффективными из-за отсутствия имущества у должника. Неразрешимой проблемой в деятельности судебных приставов-исполнителей является факт отчуждения имущества должником еще «до» или «во время» судебного разбирательства, по результатам которого вынесен исполнительный документ. В этом случае при отсутствии или недостаточности имущества у должника для исполнения требований исполнительного документа судебный пристав-исполнитель должен окончить исполнительное производство без фактического исполнения. Между тем зачастую судебный пристав владеет информацией, что должником до возбуждения исполнительного производства совершены действия по отчуждению, принадлежащего ему имущества с пользу родственников, несовершеннолетних детей, супругов. [4, с.105-112]. Данный вопрос нашел отражение в Постановлении Пленума Верховного суда РФ от 17.11.2015 № 50 «О применении законодательства при рассмотрении некоторых вопросов, возникающих в ходе исполнительного производства». В указанном акте суд разъяснил, что ввиду неиспчерпывающего перечня полномочий судебного пристава-исполнителя, перечисленных в ч.1 ст. 64 Закона об исполнительном производстве судебный пристав-исполнитель вправе совершать иные действия при условии, что они соответствуют целям и задачам исполнительного производства, а также не нарушают права должника и иных лиц. Другим Постановлением Судебной коллегией по гражданским делам Верховного суда РФ к иным полномочиям судебных приставов-исполнителей было отнесено право последнего на обращение с иском в суд о признании сделки в отношении арестованного имущества должника недействительной, если при ее совершении имело место злоупотребление правом со стороны должника по исполнительному производству. [Определение Судебной коллегии по гражданским дела Верховного суда от 18.04.2017 г.по делу № 77-КГ171]. При этом суд мотивировал свое решение отсутствием в законе прямого запрета на оспаривание сделок судебным приставами со ссылкой на пункт 3 ст. 166 ГК РФ.

Однако толкование Верховным судом Российской Федерации законодательства об исполнительном производстве в 2015 г. и вынесение им правоприменительного акта в 2017 году никак не повлияло на практику судебных приставов-исполнителей по предъявлению исков о признании сделок недействительными и применении последствий недействительности ничтожной сделки. Отсутствие в Законе об исполнительном производстве прямого указания на право судебного пристава-исполнителя по оспариванию сделок должника существенно ограничивает и прокурора при осуществлении надзорных полномочий. На практике это выражается в том, что прокурор, проводя проверку исполнения законов, например, действиях судебного пристава-исполнителя, выразившегося в бездействии, должен оценить полноту совершения органом принудительного исполнения исполнительных действий. Требование полноты проведения проверки распространяется и на органы прокуратуры, которые должны оценить весь комплекс произведенных действий судебным приставом. В связи с этим прокурор проверяет факт осуществления приставом каждого из полномочий, предоставленных статьей 64 Закона об исполнительном производстве с учетом стадии исполнения. В этой связи перед прокурором встает 
разумный вопрос: сколько должно быть совершено действий судебным приставом-исполнителем, чтобы действия судебного пристава могли быть квалифицированы как законные и не попали в разряд «бездействие»? Представляется, что ключом является требование полноты осуществленных судебным приставом исполнительных действий или осуществление всех предусмотренных законом полномочий. При проведении проверки в таком ключе перед прокурором логичным образом встанет задача выяснить, какие иные действия, предусмотренные ч.1 ст.64 Закона об исполнительном производстве, предпринял судебный пристав. Однако вследствие отсутствия конкретизации данного полномочия любое произведенное приставом действие, совершенное в рамках закона и не отнесенное к перечисленным анализируемой статьей полномочиям, прокурор должен признать законным. При этом в случае с правом органов принудительного исполнения на оспаривание сделок и применения последствий недействительности ничтожной сделки, то отсутствие прямого указания в законе на данное полномочия лишает прокурора требовать его исполнения, признавать действия судебного пристава незаконными или вообще бездействием, выносить акты прокурорского реагирования.

На основании вышеизложенного, полагаем, что законодательством об исполнительном производстве должно быть регламентировано полномочие судебных приставов - исполнителей в ходе осуществления исполнительных действий подавать исковое заявление в суд о признании сделки недействительной и применения последствий недействительности ничтожной сделки, если в ходе ее совершения имело место злоупотребление должником правом. Указанная норма возложит на судебных приставов не только право, но и обязанность по обращению с иском в случае, если у судебного пристава будут основания полагать, что должник действовал в обход закона и преследовал противоправную цель - избежать обращения взыскания на принадлежащее ему имущество. К поводам предъявления иска можно отнести, например, выявления факта отчуждения имущества в пользу родственников, несовершеннолетних детей, заключение договора дарения имущества. Так как факт оспаривания сделки, совершенной до возбуждения исполнительного производства, может нарушить права и законные интересы иных лиц, то для защиты интересов сторон сделки полагаем целесообразным данную категорию гражданских дел сделать обязательной для участия прокурора в порядке части 3 статьи 45 ГПК РФ в форме вступления в уже начавшийся процесс с целью дачи прокурором заключения по делу.

Расширив полномочия судебных приставов по осуществлению исполнительных действий, у органов принудительного исполнения появится обязанность совершения указанных действий при наличии оснований, а у прокурора - право требовать в установленном законодательством о прокуратуре порядке устранения нарушений закона в действиях судебных приставов. В целом же указанное правомочие будет способствовать повышению эффективности в деятельности судебных приставов по исполнению судебных актов и иных исполнительных документов.

\section{ЛИТЕРАТУРА}

1. Федеральный закон от 02.10.2007 № 229-Фз «06 исполнительном производстве»// Российская газета, № 223. 06.10.2007 г.

2. Обзор судебной практики по оспариванию постановлений, действий (бездействия) должностных лиц ФССП России в 2016 г.// ПС КонсультантПлюс.

3. Определение Судебной коллегии по гражданским дела Верховного суда от 18.04.2017 г. по делу № 77-КГ17-1// СПС КонсультантПлюс.

4. Свириденко 0.М. Оспаривание сделок во вред кредиторам вне процедуры банкротства (внеконкурсное оспаривание) // Актуальные проблемы российского права. 2020. N 2. С. 105 - 112.

5. ербинина М. Новые полномочия судебного пристава // ЭЖ-Юрист. 2015. N 49. С. 3.

(c) Гадиятова Мария Витальевна (gadiyatovam@inbox.ru ).

Журнал «Современная наука: актуальные проблемы теории и практики» 